\title{
Investment Awareness Among Young Generation
}

\author{
Zainal Azhar ${ }^{1}$, Juliza $^{1 *}$, Nor Azilah ${ }^{1}$, Amirul Syafiq ${ }^{1}$ \\ ${ }^{1}$ Faculty of Business and Accountancy, Universiti Selangor \\ Email: juliza@unisel.edu.my,
}

\begin{abstract}
Young generation these days are more creative and technology savvy than the older generation socially and financially. One particular question may arise on whether this generation is concerned about and aware of their financial status in the future and investment. This research seeks to examine the awareness towards investment among young generation. This study used primary data by questionnaire, and the samples chosen are the young generation aged from 18 to 28 years old. Based on our reading in the literature of awareness, there are three independent variables identified; financial literacy, personal interest, and environment that relate to the dependent variable, the awareness on investment. The objective of this is to examine the relationship awareness and the fore-mentioned independent variables. The result reveals that the key driven on investment among young generation is significantly based on independent variables selected. Finally, the limitations and recommendations are included to help further researchers to have a better finding of the result.
\end{abstract}

Keywords: Awareness, Environment, Financial Literacy, Investment, Personal Interest, Young Generation

JEL Classification: G02

\section{Introduction}

Malaysia, in the process of becoming a "high-income status" nation by 2020, is struggling to solve the issues of the increase in the number of young people who are grappling with higher debts more than they can handle. Reuters reported that even though the bad debts at Malaysia banks are still low, the number of people who are below 35 who have declared to be a bankrupt is highly noticeable. The heavy household burden and other personal consumption such as homes and cars are mainly the major contributions to this problem. Hence, savings and investment can become one of the answers to mitigate the situation. People invest their money to aim and target to get good returns and enough liquidity and safety. Investment can be a wonderful way to generate income and asset (Murlidhar, 2015).

Investment is generally defined as an asset that an investor owns or controls, directly or indirectly, and that has the characteristics as the commitment of capital or other resources, the anticipation of gain or profit, or the assumption of threat (Malik, 2008). The expectation to gain or to experience any financial risk might happen in the future. Meanwhile, Phillips (2005) argues that the awareness is the subject related to self-discrepancies and emotion. This discrepancy has a tendency to create an alert alarm to own self reaction. 
Investment has its pros and cons. In a mean time the awareness on investment especially among young generation is yet to be described. Therefore, the researchers are interested to find the factors that influence the awareness of the young. Specifically, the objectives of this paper are:

1. To identify the relationship between financial literacy and investment awareness among young generation;

2. To examine the relationship between investment activities and investment awareness among young generation; and

3. To study the relationship between environment and investment awareness among young generation.

According to Standard \& Poor's in the August 2015 report, Malaysian households are accumulating debts quicker than their incomes are developing, which will likely lead to repayment problems when the credit cycle turns. Sadly, Malaysia has been noted as having the highest personal debts among 14 Asian economies, with the rate bound to 88 percent of the gross domestic product from around 60 percent in 2008. Also as reported by Malaysia's Department of Insolvency, about 5,547 individuals under the age 35 were declared bankrupt in 2014, which was more than double the number in 2005, the first year when such data were circulated. In the same year of 2014, the number of under the age of 25 was 635 which was triple the year-earlier figure. The country's ruling states that a person can be declared bankrupt if a creditor shows there is an outstanding debt of at least RM 30,000. This reality gives such solid evidence on how serious the issues are. Thus, this study is central to have a clearer understanding about the investment and how important it is for young generation to be aware of investment and its related variables, so it can be an idea to help reduce the amount of bankruptcy in the country.

\section{Literature Review}

\subsection{Awareness on Investment}

While making an investment activity, investors normally tolerate the sacrifice of certain present value for the uncertain future reward. It could entail arriving numerous decisions, such as what type of instruments to be invested, mixed instruments, the amount of investment, timing consideration, and etc. A standard finance theory assumes that investor decision towards investment must be made rationally, while the behavioral finance assumes that the investors are basically deviated from rational decision making (Sewwandi, 2015). People easily fall into confusion between savings and investment, while thinking about the investment as a means of savings. This becomes as one of the factors to reduce the tendencies of making investment among people (Lokhande, M. A., 2015). Alex Wang (2011) emphasizes that variables like awareness, income level, and skills play a mainstream role which might influence young generation to invest in some specific financial instruments. One thing is clear from the literature that investment could generate an income to the investor if it is properly managed, and the right investment tool is chosen and timely monitored. Moreover, this gain or profit can be obtained only when there are emotion and influence factors towards doing investment activities. 


\subsection{Financial Literacy on Investment Awareness}

In a study conducted by Azizah, Nurfadhilah, Ramesh, and Mior (2013), they define financial literacy as the ability to read, interpret and analyze, manage the money, communicate about personal financial conditions that affect material well-being, compute, develop independent judgment, and take actions resulting from those processes in order to thrive in our complex financial world. It also includes the ability to discern financial choices, discuss money and financial issues without discomfort, plan for the future, and respond competently to life events that affect every day financial decisions, including events in the general economy. An important element called financial literacy becomes more important when there is a deregulation of financial market, and the things make it easy to access creditors. As it has a strong competitive environment between financial institutions to increase their market share (Beal \& Delpachitra, 2003; Abraham \& Marcolin, 2006). Hence, the financial literacy gives university students capacity to prevent them from the tendency being trapped with extensive debts, especially the credit card debts (Azizah, 2013). The problem of high debt levels has deteriorated due to low financial literacy and poor financial management among some college students (Goetz, Desai, Mimura, \& Cude, 2008).

Meanwhile, Shockey and Seiling (2004) experimented with a group of lower $\neg$ income investors that were given a formal education and expenditure tracking exercises in a financial asset building program, and these participants were at all stages of financial behavior change. The researchers found out that $60 \%$ of their samples learned the most about their financial practices through their own experiences with tracking and less than $20 \%$ of their sample found formal classes or comments learning about their personal financial behaviors from friends. Larimer $\&$ Cronce (2002), however, discovered that the best way for awareness to be raised is by self $\neg$ discovery.

\subsection{Personal Interest towards Investment Activities}

Sadly, the debt level among college graduates has increased significantly over the past decade (Boushey, 2005). Hence, there is a significant societal implication as recent debts burdened college graduates may have less flexibility in the types of jobs they are able to recognize. On top of that point, decisions about marriage, family, and home purchase may also be influenced (Boushey, 2005). A recent study by Sewwandi (2015) supported by Shefrin and Statman (1985) points out that the majority of individual investors did their investment activities concerning the future returns of the stock they have bought and the amount of return for the stock that they have sold. Individual attitude towards money is the most extremely emotional related. Unlike consumer goods, when taking decision to purchase a financial product, people do not really go for a brand, but they depend on the advice of financial intermediaries in the final decision (Lewis, 2008). Somehow, the scenario shows that these investors prefer the guaranteed return given by financial institutions.

\section{$2.4 \quad$ Environment Condition towards Investment Awareness}

The primary market starts from broad environmental factors to the industry, which influences the share price and finally the tendency to analyze the knowledge potential by considering possible risks associated with securities for public investing. Income and risk factors play a significant role while selecting a product of an investment as it can create an opportunity for 


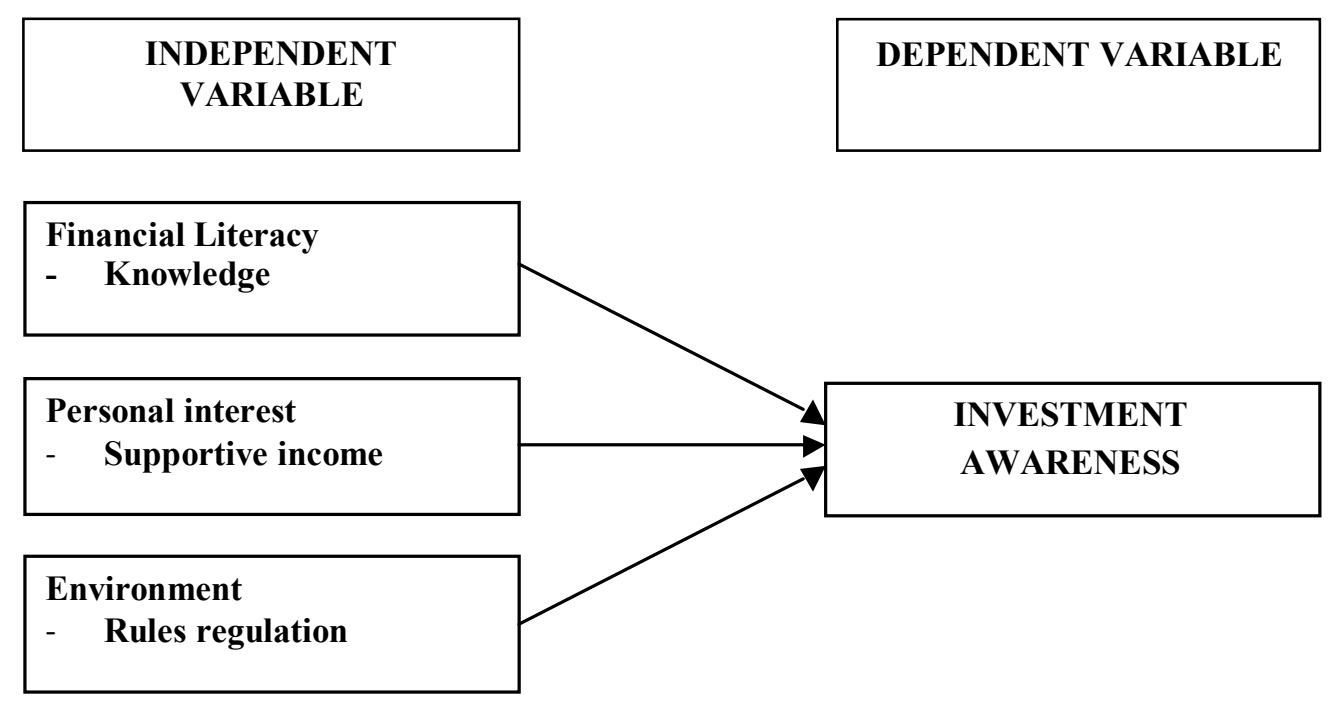

Figure 1. Research Framework

one product and may not for other products. Prasana's (2012) study on investment confirms that the impact of income and risk on the investment pattern of investors is important. A proper monetary policy will give a direction and influence to the investment house in managing potential investor demands. By having a great monetary policy, it should no doubt lead to promote acute inflationary pressures. Chander, S., \& Singh, J. (2004) postulate that price inflation will destroy the purchasing power of investment; thus, a good monetary policy will turn around the perception and encourage potential investors to spend as the current practice of investment can be categorized in a wide spectrum and view. Changes in an investment instrument have brought a variety of reasons to make an investment. Sujit and Amrit (1996) have agreed that one of the factors that might influence the salaried and business class group to invest in a mutual fund is tax benefit. Chander, S., \& Singh, J. (2004) highlight that salaried investors and professional perfected to have disclosure of net asset value on a day-to-day basis want to make an investment in order to get higher tax rebates. Kasilingam and Jayapal (2010), on the other hand, identify that family occasion and standards of living are the choice why individual is more likely to buy financial instruments in a long term return.

\section{$2.5 \quad$ Research Hypotheses}

In line with the objective of identifying the relationship between knowledge, student interest, and environment with their awareness in investment, the following hypotheses are formulated:

H1: There is a significant relationship between financial literacy and investment awareness of young generation.

$\mathrm{H} 2$ : There is a significant relationship between personal interest and investment awareness of young generation.

H3: There is a significant relationship between environment and investment awareness of young generation.

\subsection{Research Framework}

This paper is to determine whether the independent variables and dependent variable are significantly related or unrelated. Based on our reading, we conceptualize this framework as shown in Figure 1. 


\section{Methodology}

Primary data were used in this study. Data were gathered using a set of questionnaires. A total of 120 questionnaires were distributed and only 100 were usable, and the research was conducted amongst the young generation around Selangor, Malaysia.

The study analysed the data using SmartPLS 3.0. PLS-SEM method is based on the iterative technique approach that maximizes the explained variances of endogenous constructs. It also well behaves like a multiple regression technique (Hair, Anderson, Tatham, \& Black, 2010). This characteristic makes the method of PLS-SEM valuable for exploratory research.

The measurement model in PLS is assessed in terms of consistency and validity which include item loading, composite reliability (CR), and average variance extracted (AVE). Item loading which is greater than 0.70 is considered as sufficient enough for the variable to be in its construct, while a value of composite reliability which is greater than 0.70 is considered to be acceptable in terms of its reliability.

Average variance extracted (AVE) determines the amount of variance captured by the construct from each of the variables due to measurement errors. As suggested by Fornell and Lacker (1981), a minimum of $50 \%$ of variance should be captured by the construct. This implies that the values of AVE should be more than 0.50 .

The structural model in PLS is examined by evaluating the path coefficients value at $5 \%$ level of significance to see the nature of the relationship between the constructs. In order to validate the model, the diagnostic checking was conducted onto the model by observing the value of R2 which determines the strength of the model. In addition, effect size was also examined using f 2 value, and the value determines the magnitude or strength of the relationships among the constructs. This helps the researchers to assess the overall contribution of the study. A value of effect size of 0.02 indicates small effects, 0.15 indicates medium effects, and more than 0.35 indicates large effects respectively (Cohen's, 1988).

\section{4. $\quad$ Results}

A total of 100 questionnaires were received (the $83.33 \%$ response rate). The analysis used 100 completed questionnaires which are sufficient based on the Hair's rule of thumb for minimum sample size required for an analysis in PLS-SEM. From all the data set, it shows that the participation of female young adults is very high (61.4\%) compared to that of male young adults (38.6\%). Since our respondents are amongst the young generation, then it is not surprising that half of respondents between 21 and 23 years' old are currently studying or working $(71.4 \%)$. Since they are still young, it can be spotted that most of them have an income of less than RM 1,000 per month $(91.4 \%)$. The complete results are displayed in Table 1 below.

SmartPLS 3.0 was utilized using algorithms, and the measurement model was evaluated for its consistency and reliability before testing the structural model. Table 2 presents the results for a measurement model which include the factor loading, CR, and AVE. All item loadings were above 0.70 , and the composite reliability for all constructs is above than 0.70 , indicating that acceptable reliability and value of AVE of at least 50\% which suggests the validity at each construct level. These three diagnostic results show that all constructs are strongly correlated with its own measure variables as shown in Table 2 below. 
Table 1. Profile of Respondents

\begin{tabular}{lc}
\hline Profile & Percentage of Frequency \\
\hline Gender & \\
Male & $38.6 \%$ \\
\hline Female & $61.4 \%$ \\
Age & \\
$18-20$ & $20.0 \%$ \\
$21-23$ & $50.0 \%$ \\
$24-26$ & $30.0 \%$ \\
Level of Education & \\
Diploma & $28.6 \%$ \\
Degree & $71.4 \%$ \\
Level of Income & \\
Below RM 1.000 & $91.4 \%$ \\
Above RM 1,000 & $8.6 \%$ \\
\hline
\end{tabular}

Table 2. Measurement Model Properties

\begin{tabular}{|c|c|c|c|c|}
\hline Construct & Item (Variables) & Item loading & Composite reliability & AVE \\
\hline \multirow[t]{5}{*}{ Awareness } & I am aware of investments & 0.700 & \multirow[t]{5}{*}{0.902} & \multirow[t]{5}{*}{0.651} \\
\hline & I am aware that investments is important in the future & 0.834 & & \\
\hline & I am aware that investments are good for financial planning & 0.934 & & \\
\hline & I am aware that investment can give more income & 0.845 & & \\
\hline & I am aware that investment has high risk & 0.752 & & \\
\hline Financial & I know how to invest & 0.758 & \multirow[t]{5}{*}{0.873} & \multirow[t]{5}{*}{0.592} \\
\hline \multirow[t]{4}{*}{ Literacy } & I know the type of investment & 0.802 & & \\
\hline & I know investment has good and bad effects & 0.811 & & \\
\hline & I know the concept of investments & 0.766 & & \\
\hline & I know where to get the information regarding investment & 0.780 & & \\
\hline \multirow[t]{5}{*}{ Personal Interest } & Return guarantee & 0.810 & \multirow[t]{5}{*}{0.870} & \multirow[t]{5}{*}{0.575} \\
\hline & I want to invest in low income & 0.799 & & \\
\hline & I know investment can give higher return & 0.793 & & \\
\hline & I am interested in investment for a long term period & 0.767 & & \\
\hline & I would like to invest in gold, mutual and chit fund to gain income & 0.872 & & \\
\hline \multirow[t]{5}{*}{ Environmen } & Political and social will affect the investment & 0.793 & \multirow[t]{5}{*}{0.907} & \multirow[t]{5}{*}{0.763} \\
\hline & Tax incentive influences the investment & 0.767 & & \\
\hline & Rising in land price forces me to invest & 0.872 & & \\
\hline & Economic condition forces me to invest & 0.811 & & \\
\hline & People around me force me to invest & 0.800 & & \\
\hline
\end{tabular}

After validating the measurement model, the structural model was run using a bootstrapping procedure of 5000 times of resampling, and the results are consistent. The path coefficients in the PLS-SEM analysis are shown in Table 3. The nature of the path coefficient shows that financial literacy has a significant impact towards awareness with a positive relationship with 0.384 ( $\mathrm{p}$-values $=0.009<0.05)$. Meanwhile, the personal interest shows that there is a statistically significance with a positive relationship by referring to the path coefficients 0.439 ( $p$-value $=0.018<0.05)$. Among these three variables, we have obtained that environment does not give an impact towards investment awareness due to the greater $\mathrm{p}$-value (0.080). Thus, this study shows that the environment has no relationship towards investment awareness. The details of the results are depicted in Table 3 below:

The strength of the relationship can be measured by observing the value of for $\mathrm{R}^{2}$. The value of $\mathrm{R}^{2}$ for this model is 0.72 and can be considered as high. About $72 \%$ of awareness level amongst 
Table 3. Structural Model Properties

\begin{tabular}{llllll}
\hline Path & Coefficients & t-statistics & p-value & $f^{2}$ & $R^{2}$ \\
\hline Financial literacy $\rightarrow$ awareness & 0.384 & 2.619 & $0.009^{* * *}$ & 0.183 & 0.720 \\
Personal Interest $\rightarrow$ awareness & 0.439 & 2.368 & $0.018^{* * *}$ & 0.164 & \\
Environment $\rightarrow$ awareness & 0.080 & 0.741 & 0.459 & 0.009 & \\
*** significance at 0.05 & & & &
\end{tabular}

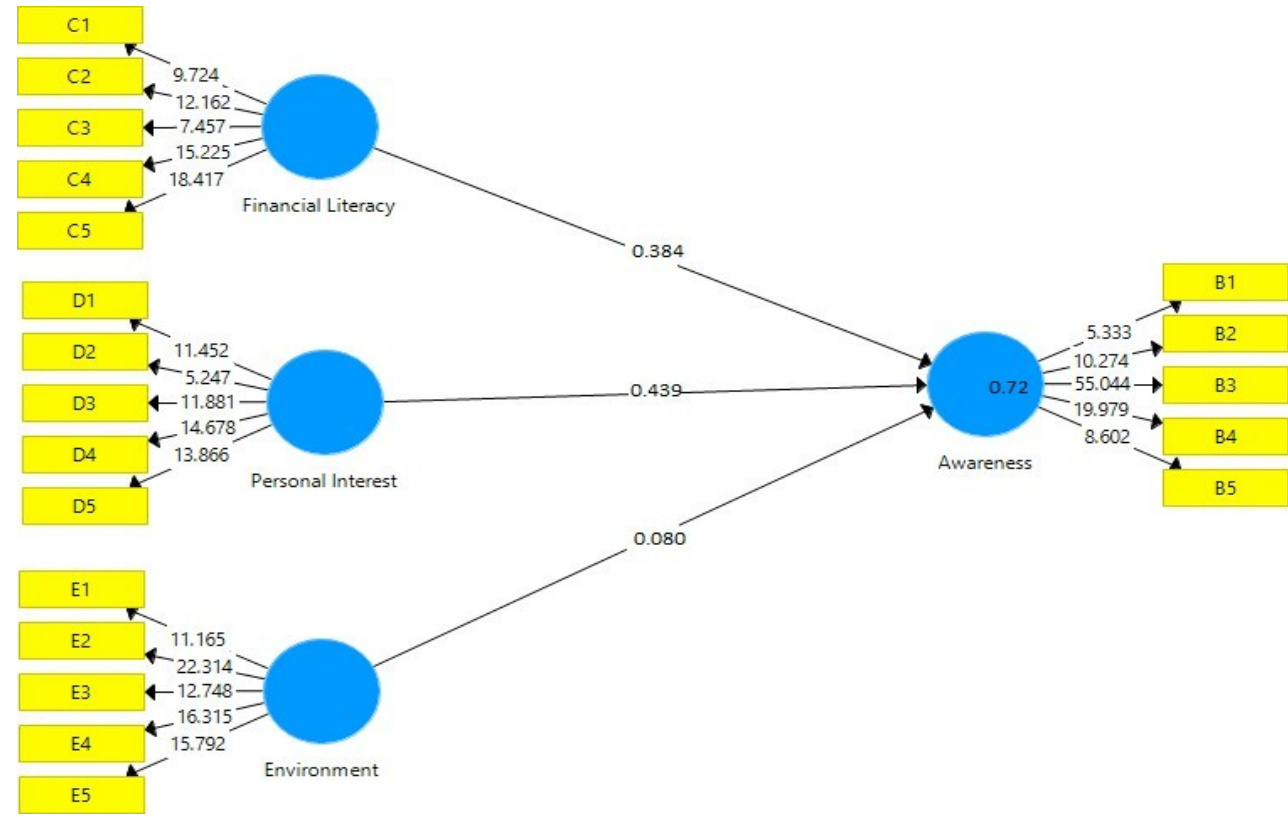

Figure 2. Structural Model

young adults in investments is explained by their financial literacy and personal interest. Somehow, the living environment contradicts with the result obtained from the significant value.

However, we examined the effect size due to the contradict result by referring to the value of $f^{2}$. The $f^{2}$ values for individual interest, environment, and financial literacy are 0.183 , 0.164 , and 0.009 respectively. This indicates that personal interest and environment have a medium effect, and financial literacy has a small effect towards awareness. The overall structural model is displayed in Figure 2.

Thus, the results obtained from this structural model confirm that awareness in investment amongst young adults is influenced by two independent variables namely personal interest and financial literacy. This is proof that these two factors give significant effects on awareness towards investments among youngsters that can be managed later.

\section{Discussion}

In this modern era, current financial market offers a better opportunity to invest. With variable investment instruments provided, it has made market more enticing with return and risk preference to be explored and grabbed by the potential investors. This study is specifically looking into the factors influencing the investment awareness among the potential investors of the youth. 
The respondents' financial literacy is found to significantly affect the investment awareness. Based on the questionnaire, the respondents' knowledge on how to invest, the type of investment, the concept, and how about getting into the information on investment should be taken seriously by the financial planners. These results are consistent with Azizah et al.'s (2013) study which emphasizes on the importance of financial literacy in terms of interpreting and managing money. The financial literacy also gives room to the young generation to avoid being trapped with a lot of debts especially the credit card debts.

The second major finding of this study is the personal interest factor. It is a crucial element in creating awareness in investment. The respondents indicated that if they were to invest, they needed to have a guaranteed return; they prefer to invest in low income and get the higher return for a longer term period. Most of them also like to invest in gold, mutual, and cheap fund. This study is consistent with Boushey's (2005) study that the society should have been more careful in managing personal interest such as the desire to have family and to purchase home as those are significantly related to investment awareness.

The environment factor is not found significant in this study. It could be because the respondents are the young generation that they are not really concerned about environment in terms of political, social, and economic situation. The findings could be different as they become more matured later. This study is not consistent with Prasana (2012) and Chander, S., \& Singh, J.'s (2004) studies.

In short, by having an appropriate investment portfolio, it will facilitate future investors to be more knowledgeable to achieve their financial goals within a particular period of time. The significance of these financial instruments is apparent in the economic acceleration of any country by channelizing the household savings. Somehow, from the young generation point of view, the awareness on investment seems to be lacking. This study deals with the young generation behavior towards an investment opportunity.

\section{References}

Alex, W. (2011). Younger generations investing behaviors in mutual funds: Does gender matter? The Journal of Wealth Management, Vol. 13, No.4, 13-23.

Azizah, N., Nurfadhilah, Ramesh, Mior, A. (2013). Financial Literacy: A study among the university students. Interdisciplinary Journal of Contemporary Research in Business, vol. 5 , no. 2 pp. $279-299$.

Beal, D. J., \& Delpachitra, S. B. (2003). Financial literacy among Australian university students. Economic Papers, 22(1), 15.

Boushey, H. (2005). Student debt: Bigger and bigger. Center for Economic and Policy Research, Washington, DC.

Cohen, J. (1988). Statistical power analysis for the behavioral sciences, 2nd ed. Lawrence Erlbaum, Hillside, NJ. 
Emily, C. (2015). Bankruptcy among the young in Malaysia crimps consumption, retrieved on 6 September 2015, from http://www.reuters.com/article/malaysia-economy-debtidUSL3N10O3QR20150906.

Fornell, C., \& Larcker, D.F. (1981). Evaluating structural equation models with unobservable variables and measurement error. Journal of Marketing Research, 18 (1), 39-50.

Hair, J.F., Anderson, R.E., Tatham, R.L. \& Black, W.C. (2010). Multivariate data analysis, 8th ed., Macmillan, New York, NY.

Hulland, J. (1999). Use of partial least squares (PLS) in strategic management research: A review of four recent studies. Strategic Management Journal, 20(2), 195-204.

Kasilingam, R. \& Jayapal, G. (2010). Characteristics of investors based on choice criteria segmentation. Journal of Management Research, 2(1), 11-25.

Larimer, M. E., \& Cronce, J. M. (2002). Identification, prevention and treatment: A review of individual-focused strategies to reduce problematic alcohol consumption by college students. Journal of Studies on Alcohol, 14(Suppl.), 148-163.

Lewis A. (2008). The Cambridge Handbook of Psychology and Economic Behavior. Cambridge University Press.

Lokhande, M. A. (2015). A study of investment awareness and patterns of savings and investments by rural investors. Indian journal of Finance, 9(7), 22-31.

Mahnaz, M. (2008). Recent developments in definition of investment in international investment agreement. Second annual forum of developing country investment negotiators, Marrakech, Morocco.

Palmer Lance, Bliss, Donna L. Goetz, Joseph W. Moorman, Diann. (2010). Improving financial awareness among college students: Assessment of a financial management project. College Student Journal, Project Innovation (Alabama).

Phillips, A. G., \& Silvia, P. J. (2005). Self-awareness and the emotional consequences of selfdiscrepancies. Personality and Social Psychology Bulletin, 31(5), 703-713.

Prasanna Chandra. (2012). Investment analysis and portfolio management, $2^{\text {nd }}$ edition, NJ: Tata McGraw Hill Education Publication Company Limited, New Delhi.

Shefrin, Hersh and M Statman. (1985). The Disposition Effect to Sell Winner too Early and Ride the Losers too Long. Journal of Finance, 40 (3), pp. 777-790.

Sikidar, Sujit, Singh, Amrit Pal. (1996). Financial Services: Investment in Equity and Mutual Funds - A Behavioral Study, in Bhatia B.S., and Batra G.S.(ed.) Management of Financial Services, NJ: Deep and Deep Publications, New Delhi, pp. 136-145.

Chander, S., \& Singh, J. (2004). Performance of mutual funds in India: An empirical evidence. The ICFAI Journal of Applied Finance, 10, 45-63. 
Shockey, S. S., \& Seiling, S. B. (2004). Moving into action: Application of the transtheoretical model of behavior change to financial education. Financial Counseling and Planning, $15(1), 41-52$.

Thushari Sewwandi. (2015). "Behavioral Biases in Investment Decision Making: A Literature Review". Conference: International Conference on Business and Information, University of Kelaniya, Volume: 6. 